\title{
Gentesting før behandling med warfarin?
}

\author{
Riktig startdose til pasienter som skal \\ behandles med warfarin, er en klinisk \\ utfordring. Gentesting før behand- \\ lingsstart kan gjøre det enklere.
}

Genetiske polymorfismer finnes både i genet som koder for målenzymet for warfarin, VKORCl og det som koder for det viktigste enzymet som bryter ned warfarin, CYP2C9. I kaukasisk befolkning er 10-15\% homozygote for en $V K O R C l$-genvariant som gir økt følsomhet for warfarin. Rundt $1 \%$ er homozygote for CYP2C9-genvarianter som gir forhøyede plasmanivåer og økt effekt av warfarin pga. nedsatt levermetabolisme. Dette øker risikoen for til dels alvorlige blødningsbivirkninger ved vanlig standarddosering av legemidlet. I tillegg er henholdsvis $30-40 \%$ og $10-15 \%$ i befolkningen heterozygote for de aktuelle mutasjonene.

Nå har man i en retrospektiv studie sammenliknet en doseringsalgoritme med utgangspunkt $i$ kliniske faktorer som alder, kjønn og behandling med øvrige legemidler med en annen algoritme som dessuten tok hensyn til VKORC1- og CYP2C9-genotypene (1). Studien omfattet 4043 pasienter.
Hos dem som trengte doser på $\leq 3 \mathrm{mg} / \mathrm{d}$ samt dem som trengte doser på $\geq 7 \mathrm{mg} / \mathrm{d}$ ( $46 \%$ av populasjonen), havnet signifikant flere i riktig INR-område ved at man beregnet dosen ved hjelp av den farmakogenetiske doseringsalgoritmen. Det gjaldt henholdsvis $49 \%$ mot $33 \%$ ved doser $\leq 3 \mathrm{mg} / \mathrm{d}$ og $25 \% \operatorname{mot} 7 \%$ ved doser $\geq 7$ $\mathrm{mg} / \mathrm{d}$. Hos dem som trengte doser på 3-7 $\mathrm{mg} / \mathrm{d}$, økte ikke genotyping treffsikkerheten. Det siste er ikke så overraskende, siden disse individene representerer «gjennomsnittspopulasjonen», som vanlig standarddosering er blitt tilpasset ut fra.

Genotyping av VKORCl og CYP2C9 er tilgjengelig ved flere laboratorier i Norge. Det trengs nå prospektive randomiserte studier for å validere algoritmen på uavhengig basis, både i forhold til klinisk og helseøkonomisk nytte.

\section{Olav Spigset}

olav.spigset@legemidler.no

Avdeling for klinisk farmakologi

St. Olavs hospital

\section{Litteratur}

The International Warfarin Pharmacogenetics Consortium. Estimation of the warfarin dose with clinical and pharmacogenetic data. N Engl J Med 2009; 260: 753-64.

\section{Risikofri prenataldiagnostikk under utvikling}

\section{En enkel blodprøve av mor kan \\ erstatte dagens tester for kromosom- feil hos fosteret.}

Invasive teknikker for å diagnostisere kromosomfeil hos fostre er forbundet med omkring $1 \%$ risiko for abort som følge av inngrepet. I dag tilbys derfor gravide med økt risiko en kombinasjon av ultralydundersøkelse og blodprøve av mor (duo-test) for å avklare situasjonen nærmere. Men et sikkert svar får man kun ved å undersøke kromosommønsteret i en prøve fra morkaken eller fostervannet.

En gruppe forskere har utviklet en teknikk der man kan påvise kromosomfeil hos fosteret ved å undersøke foster-DNA i blodprøver fra mor (1). Selv om DNA fra fosteret bare utgjør mindre enn $10 \%$ av det totale DNA i mors blod, klarte man ved hjelp av såkalt «shotgun»-sekvensering å påvise selv beskjedne økninger i DNAmengden fra ett bestemt kromosom. Hos 18 gravide fikk alle 12 med kromosomfeil riktig diagnose.

- Fordi mengden foster-DNA i mors blod først i uke 14 er høy nok til at metoden er tilstrekkelig følsom, er den kliniske nyttever- dien begrenset, sier seksjonsoverlege Gunnar Houge, Senter for medisinsk genetikk og molekylærmedisin, Haukeland universitetssykehus. Noe av det viktigste ved prenatal diagnostikk er å få stilt diagnosen så raskt som mulig. I dag er svarene på ultralydundersøkelsen og duo-testen klare i uke 12, og en eventuell chorionbiopsi kan tas rett etterpå.

- Hvis metoden forbedres slik at testen kan gjøres tidligere, kan den ha store fordeler. Dette gjelder særlig dersom dagens regler, som er basert på et 25 år gammelt rundskriv fra Helsedirektøren, for hvem som får tilbud om prenatal diagnostikk oppmykes og pasientantallet øker. Flere pasienter vil da trenge diagnostisk avklaring av en forhøyet risiko. Dersom vi kan tilby en risikofri blodprøve fremfor en morkakebiopsi, vil unødvendige aborter kunne unngås.

\section{Ragnhild Ørstavik \\ ragnhild.orstavik@fhi.no \\ Tidsskriftet \\ Litteratur \\ Fan HC, Blumenfeld YJ, Chitkara U et al. Non- invasive diagnosis of fetal aneuploidy by shotgun sequencing DNA from maternal blood. Proc Natl Acad Sci USA 2008; 105: $16266-71$.}

Mulig sammenheng mellom medikamentbruk og preeklampsi Kvinner som bruker selektive serotoninreopptakshemmere (SSRI) under graviditet har økt risiko for å utvikle hypertensjon og preeklampsi, viser en intervjuundersøkelse av 5000 kvinner (Am J Psychiatry 2009; 166: $320-8)$. Risikoen var størst for kvinner som hadde brukt SSRI-midler gjennom hele svangerskapet. Hos disse var forekomsten av mulig preeklampsi hele $15 \%$ fem ganger høyere enn blant ikke-brukere.

Ut fra studiens design var det ikke mulig å se på om det er medikamentene eller grunnsykdommen som forårsaket hypertensjon og preeklampsi. Derfor skriver forfatteren av en kommentarartikkel i samme nummer (s. 268-70) at kvinner som bruker SSRI-midler når de blir gravide, ikke bør slutte dersom det er stor fare for at depresjonen forverres.

\section{Melamin i morsmelkerstatning}

Melamin øker proteininnholdet i matvarer, men brytes ikke ned i kroppen. I 2008 døde seks kinesiske barn fordi de drakk morsmelkerstatning som var tilsatt melamin, og mange flere fikk nyrestein. Helsemyndighetene i Kina tilbød gratis screening av barn for å utelukke nyrestein.

Nå er resultatet av screeningunders $\varnothing$ kelsene publisert: En av undersøkelsene viser at barn som hadde fått melaminholdig melk, hadde sju ganger så høy risiko for nyrestein som andre (N Engl J Med 2009; 360: 1067-74). Men de hadde sjelden symptomer, og forekomsten av blod og leukocytter i urinen var ikke forhøyet. Det anbefales imidlertid ikke at kinesiske barn bosatt $i$ andre land som kan ha drukket melaminholdig melk, rutinemessig screenes for forekomst av nyrestein.

\section{Søvnproblemer} \section{går sjelden over av seg selv}

En studie av det naturlige forløpet ved søvnproblemer viser at $75 \%$ av dem som rapporterer søvnvansker ved starttidspunktet, også har det etter ett år, og halvparten etter tre år (Arch Intern Med 2009; 169: 447-53). Et kronisk forløp var mer vanlig hos kvinner enn hos menn, og vanligst hos dem med alvorlige plager.

Studien omfattet nesten 400 voksne med insomni eller lettere søvnforstyrrelser. Deltakerne svarte på validerte spørreskjemaer om søvnsykdommer fire ganger i løpet av studieperioden. 